\title{
Bioeconomic Modelling to Assess the Impacts of Using Native Shrubs on the Marginal Portions of the Sheep and Beef Hill Country Farms in New Zealand
}

\author{
James Chege Wangui ${ }^{1,2, * \mathbb{D}}$, Paul R. Kenyon ${ }^{2}$, Peter R. Tozer ${ }^{2}$, James P. Millner ${ }^{2}$ and Sarah J. Pain ${ }^{2}$ \\ 1 Department of Livestock Production, County Government of Wajir, P.O. Box 545, Wajir 70200, Kenya \\ 2 School of Agriculture and Environment, Massey University, Private Bag 11 222, \\ Palmerston North 4442, New Zealand; p.r.kenyon@massey.ac.nz (P.R.K.); P.Tozer@massey.ac.nz (P.R.T.); \\ j.p.millner@massey.ac.nz (J.P.M.); S.J.Pain@massey.ac.nz (S.J.P.) \\ * Correspondence: j.wangui@massey.ac.nz
}

check for updates

Citation: Wangui, J.C.; Kenyon, P.R.; Tozer, P.R.; Millner, J.P.; Pain, S.J.

Bioeconomic Modelling to Assess the Impacts of Using Native Shrubs on the Marginal Portions of the Sheep and Beef Hill Country Farms in New Zealand. Agriculture 2021, 11, 1019. https://doi.org/10.3390/ agriculture11101019

Academic Editor: Sanzidur Rahman

Received: 29 August 2021

Accepted: 13 October 2021

Published: 18 October 2021

Publisher's Note: MDPI stays neutral with regard to jurisdictional claims in published maps and institutional affiliations.

Copyright: (c) 2021 by the authors. Licensee MDPI, Basel, Switzerland. This article is an open access article distributed under the terms and conditions of the Creative Commons Attribution (CC BY) license (https:// creativecommons.org/licenses/by/ $4.0 /)$.

\begin{abstract}
New Zealand hill country sheep and beef farms contain land of various slope classes. The steepest slopes have the lowest pasture productivity and livestock carrying capacity and are the most vulnerable to soil mass movements. A potential management option for these areas of a farm is the planting of native shrubs which are browsable and provide erosion control, biodiversity, and a source of carbon credits. A bioeconomic whole farm model was developed by adding a native shrub sub-model to an existing hill country sheep and beef enterprise model to assess the impacts on feed supply, flock dynamics, and farm economics of converting 10\% (56.4 hectares) of the entire farm, focusing on the steep slope areas, to native shrubs over a 50-year period. Two native shrub planting rates of $10 \%$ and $20 \%$ per year of the allocated area were compared to the status quo of no $(0 \%)$ native shrub plantings. Mean annual feed supply dropped by $6.6 \%$ and $7.1 \%$ causing a reduction in flock size by $10.9 \%$ and $11.6 \%$ for the $10 \%$ and $20 \%$ planting rates, respectively, relative to $0 \%$ native shrub over the 50 years. Native shrub expenses exceeded carbon income for both planting rates and, together with reduced income from sheep flock, resulted in lower mean annual discounted total sheep enterprise cash operating surplus for the 10\% (New Zealand Dollar (NZD) 20,522) and 20\% (NZD 19,532) planting scenarios compared to $0 \%$ native shrubs (NZD 22,270). All planting scenarios had positive Net Present Value $(N P V)$ and was highest for the $0 \%$ native shrubs compared to planting rates. Break-even carbon price was higher than the modelled carbon price (NZD 32/ New Zealand Emission Unit (NZU)) for both planting rates. Combined, this data indicates planting native shrubs on $10 \%$ of the farm at the modelled planting rates and carbon price would result in a reduction in farm sheep enterprise income. It can be concluded from the study that a higher carbon price above the break-even can make native shrubs attractive in the farming system.
\end{abstract}

Keywords: bioeconomic modelling; native shrubs; cash operating surplus; hill country; sheep

\section{Introduction}

Sheep and beef cattle in New Zealand are managed together to complement pasture utilization [1] and they contribute more than $95 \%$ of the red meat produced that is available for export [2]. In 2020, there were approximately 26 million sheep and 3.89 million beef cattle in New Zealand [3,4]. Sheep and beef cattle farms occupy approximately 63\% of agricultural land with over half of the farms located on hill country [5].

Hill country is classified as land below 1000 meters containing slopes greater than $15^{\circ}$ and accounts for approximately $37 \%$ of the farmed land in New Zealand [6]. The slopes across hill country farms differ but are generally a mixture of low $\left(<7^{\circ}\right)$, medium $\left(8^{\circ}\right.$ to $\left.20^{\circ}\right)$, and steep $\left(>21^{\circ}\right)$ slope classes [2,7]. Land use and productivity varies with slope; low and medium slopes are mainly planted with improved pastures while less grazable steep slopes may be used for grazing or utilized for plantation forestry with the non-utilizable 
portions allowed to revert to native vegetation $[1,2,8]$. Even with improved pastures, low herbage production on the steep slopes limits their use for grazing, often with a carrying capacity of less than eight stock units per hectare $[6,9,10]$.

Native vegetation on hill country sheep and beef farms represents approximately $12 \%$ of the national native flora cover $[5,11]$, indicating the contribution these farm types are making to revegetation and restoration of native flora. The low native vegetation cover resulted from clearance for pasture expansion in the early 1900s, which exposed some hill country to the vulnerability of soil mass movement, environmental degradation, and loss of native biodiversity [6]. Attempts to mitigate soil mass movement in hill country have utilized spaced exotic species such as poplars (Populus spp.) and willows (Salix spp.) [12] and land use change to plantation forestry with radiata pine (Pinus radiata) [13]. Poplars and willows are comparatively easy to establish, have deep and expansive roots that stabilize steep slopes [12-14], can supply valuable fodder [15,16], and, if well-spaced, can provide carbon trade income [14,17], but they are deciduous and management intensive [18]. Plantation forestry can provide erosion control and income from carbon trade and sale of logs but their monoculture limits biodiversity, understory grazing, and can result in accelerated erosion during and after harvesting if not replanted [8].

An alternative to exotic species is the use of native trees and shrubs which are endemic and adaptable to New Zealand conditions [11]. Additionally, native plants are culturally valued, can enhance biodiversity restoration, control erosion, improve landscape aesthetics, provide income from carbon trade, and can be a potential source of fodder to livestock [11, 19-21]. However, knowledge on the management of cultivated native shrubs in New Zealand and their role in erosion control, fodder production and their nutritive value for livestock, and the economics of establishing them on the hill country sheep and beef farms is lacking $[19,22]$. Bioeconomic modelling of establishing native shrubs on the hill country sheep and beef farms using the limited literature data available can provide these insights.

Hill country sheep and beef farms are complex and dynamic systems consisting of biophysical, social, and economic components which interact and influence farm sustainability and profitability [23,24]. Models integrating both biophysical and economic components, commonly referred to as bioeconomic models, are more robust in evaluating impacts of changing farming practices or applying a new intervention [23]. Farrell et al. [25-28] have previously utilized a bioeconomic model for North Island hill country to examine the impacts of various changes in sheep and beef cattle systems. However, as with many models used for hill country sheep and beef farm systems [29,30], that model does not consider native shrubs as part of economic land use. Therefore, the objective of this study was to develop a native shrub sub-model to add to the existing model developed by [24] and use it to assess the impacts on:

(i) farm feed supply,

(ii) flock dynamics, and

(iii) farm economics of converting $10 \%$ of a North Island hill country sheep and beef farm from only pasture production to native shrubs with understory grazing.

\section{Materials and Methods}

\subsection{Model Development and Structure}

A bioeconomic whole-farm system dynamics model has been developed in STELLA Architect version 1.9.3 (version 2019, isee systems, Lebanon, NH, USA) to represent a North Island hill country sheep and beef enterprise in New Zealand based on the model of [25]. The model assessed changes in feed, sheep numbers, and cash flow dynamics for 50 years, with and without a portion of the farm (up to 10\%) planted in native shrubs over a 5- or 10-year period. The model combined the established hill country sheep and beef enterprise model (HCM) utilized by $[25,27,31,32]$ with a new native shrub sub-model (NSM) and was structured into modules representing biophysical and economic sub-systems and their interactions (Figure 1). Details on the dynamics of the HCM are outlined in [25]. 
The established HCM model [25] assumed that the hill country terrain was constant across the entire farm and, therefore, the pasture yield and quality per hectare were uniform. Further, pastures supplied all the flock feed needs and that the sheep and beef enterprises were the only source of farm cash flow [25]. However, hill country farms are characterized by a mixture of topographies which can influence pasture production and quality, thus affecting farm animal carrying capacity and cash flow [6,33]. Moreover, hill country sheep and beef farms often use supplementary feeds, such as conserved pasture, crops, grains, and tree and native shrub herbage, during seasons of low feed quantity and energy supply [1]. In addition, hill country farms can have diverse income including sale of logs [34] and the carbon credit $[19,35]$. Therefore, a new NSM model was developed to allow:

(i) partitioning of the hill country farm into various topographical land classes that vary in pasture growth and quality,

(ii) use of native shrubs as a feed source,

(iii) diversification of land uses to encompass native shrub land, and

(iv) expansion of sources of farm income to include carbon emission trading.

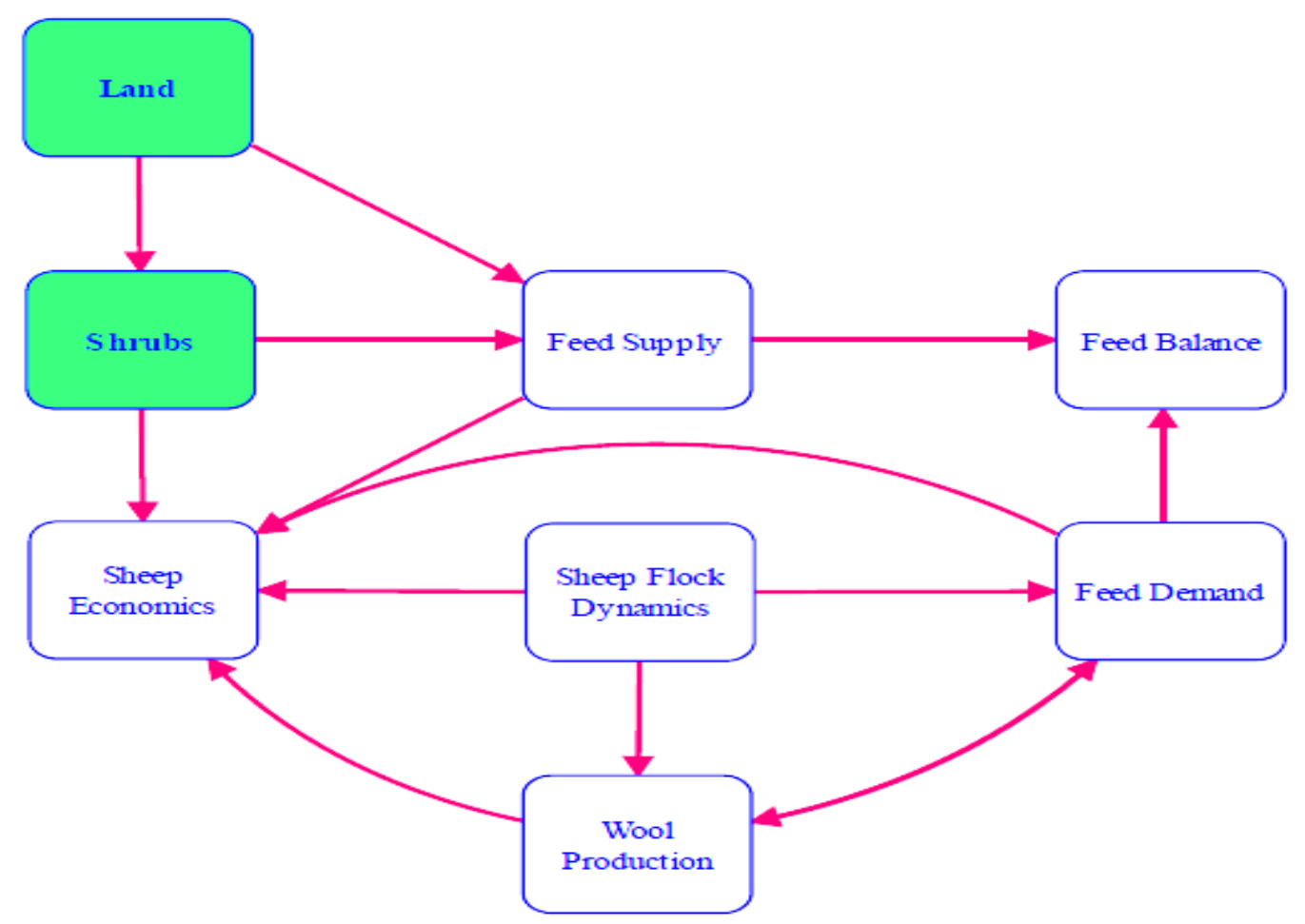

Figure 1. A simplified diagram of the North Island hill country sheep and beef whole farm system dynamic model comprising modules of the hill country sheep enterprise (HCM) (white fill based on Farrell et al. (2019) and native shrub (NSM) models (green fill)). The arrows indicate the direction of interaction among the modules.

\subsection{Land Characteristics for Modelled Farm}

In New Zealand, North Island hill country sheep and beef farms can be sub-divided into hard hill and hill country based on slopes and land use capability [36]. North Island hard hill country farms are predominantly steep with characteristically low soil fertility and a carrying capacity of less than 10 stock units per hectare (SU/ha, $1 \mathrm{SU}$ equals the annual feed requirement of a $55 \mathrm{~kg}$ ewe rearing 1 lamb to weaning at $28 \mathrm{~kg}$ ), whereas North Island hill country farms have relatively less steep topography with greater soil fertility and, therefore, a higher livestock carrying capacity of up to $13 \mathrm{SU} /$ ha $[36,37]$. Hill country farms contain a mixture of slopes [38] that can be grouped broadly into low (flat), medium (moderate), and steep slope classes $[10,13,39]$. The blend of slopes varies across 
farms and regions, resulting in disparities among studies on slope classes (Table 1) and their proportion on a hill country farm (Table 2). Therefore, for the current model, a typical farm with a productive land area of approximately 564 ha in the East Coast region of New Zealand [37] was used as the archetype for the North Island hill country farm. Sheep and beef cattle farms in the East Coast region can be grouped into hard hill (class 3 ) and hill country (class 4) farms based on land usability [37]. The East Coast region of New Zealand was chosen due to the dominance of hill country terrains [39-41]; the region also accounts for approximately $50 \%$ of the North Island sheep population [4] and was the base region for the existing bioeconomic model of [25].

Based on published data, the slope types of the modelled North Island hill country sheep and beef farm were grouped into low $\left(<12^{\circ}\right)$, medium $\left(13^{\circ}\right.$ to $\left.25^{\circ}\right)$, and steep $\left(>25^{\circ}\right)$ slope classes $[33,42]$ to capture the critical slopes relevant to pastoral land use [38] and pasture production [43]. Slope classes were apportioned as $8.7 \%, 45.9 \%$, and $45.4 \%$ in the low, medium, and steep slope classes, respectively, and were used to reflect the average slope mix of East Coast hill country farms [39], Table 2. The model assumed that approximately $10 \%$ ( $56.4 \mathrm{ha}$ ) of the total effective land area of the farm would be used for planting native shrubs. This area was assumed to be part of the steep slope $\left(>20^{\circ}\right)$ portion of the farm due to its low carrying capacity (herbage production) and vulnerability to erosion [44].

Table 1. Published classifications of North Island sheep and beef hill country farm slopes based on slope classes (low, medium, and steep).

\begin{tabular}{|c|c|c|c|}
\hline \multicolumn{3}{|c|}{ Slope Elevation $\left({ }^{\circ}\right)$} & \multirow{2}{*}{ Author (s) } \\
\hline Low & Medium & Steep & \\
\hline$<7$ & 8 to 20 & $>21$ & [5] \\
\hline$<15$ & 16 to 20 & $>21$ & [7] \\
\hline$<12$ & 12 to 24 & $>24$ & {$[13,39]$} \\
\hline 1 to 12 & 13 to 25 & $>26$ & {$[6,9,33,42,45]$} \\
\hline 0 to 10 & 10 to 24 & 25 to 37 & [46] \\
\hline$<15$ & 15 to 25 & $>25$ & [10] \\
\hline 0 to $3(\mathrm{~A}), 4$ to $7(\mathrm{~B}), 8$ to $15(\mathrm{C})$ & 16 to $20(\mathrm{D}), 21$ to $25(\mathrm{E})$ & 26 to $35(\mathrm{~F}),>35(\mathrm{G})$ & {$[38,42,47,48]$} \\
\hline 0 to $3(\mathrm{~A}), 4$ to $7(\mathrm{~B}), 8$ to $15(\mathrm{C})$ & 16 to 20 (D) 21 to 25 (E) & 26 to $35(\mathrm{~F}), 35$ to $42(\mathrm{G}),>42(\mathrm{H})$ & [49] \\
\hline
\end{tabular}

(A) Flat, (B) undulating, (C) rolling, (D) strongly rolling, (E) moderately steep, (F) steep, (G) very steep, and (H) extreme (near vertical) steep refers to extra slope classes grouping.

Table 2. Published proportions of the three slope classes (low, medium, and steep) as percentage of the total hill country farm in New Zealand.

\begin{tabular}{|c|c|c|c|c|}
\hline \multicolumn{3}{|c|}{ Slope Class Proportion (\%) } & \multirow{2}{*}{ Scope of the Study } & \multirow{2}{*}{ Author } \\
\hline Low & Medium & Steep & & \\
\hline 11.0 & 32.0 & 40.0 & New Zealand & [5] \\
\hline 19.6 & 34.5 & 45.9 & New Zealand & [39] \\
\hline 55.0 & 13.0 & 35.0 & New Zealand & [7] \\
\hline 30.1 & 12.8 & 57.1 & North Island & [48] \\
\hline 10.0 & 18.0 & $60.0,12.0^{1}$ & East Coast (Gisborne) & [49] \\
\hline 8.7 & 45.9 & 45.5 & East Coast & [39] \\
\hline 14.5 & 57.9 & 27.6 & Northland-Waikato-Bay of Plenty & [39] \\
\hline 11.2 & 27.7 & 61.1 & Taranaki-Manawatu & [39] \\
\hline 15.6 & 15.8 & 68.5 & Marlborough-Canterbury & [39] \\
\hline 36.6 & 29.7 & 33.7 & Otago-Southland & [39] \\
\hline 14.1 & 15 & 70.9 & Wairarapa & [50] \\
\hline
\end{tabular}




\subsection{Modelled Native Shrubs Planting on the Hill Country Farm}

Two annual native shrub planting rates of $10 \%$ and $20 \%$ were applied to mimic the likely land use change scenarios that could occur with establishment of native shrubs. The native shrub planting rates determined the proportion of the area set aside for planting native shrubs that was planted annually. The $10 \%$ planting rate assumed the 56.4 ha set aside for planting native shrubs was divided into ten portions that were planted consecutively for ten years. Similarly, the planting rate of $20 \%$ assumed the area was divided into five equal portions which were planted over five consecutive years. When no native shrubs were planted, a $0 \%$ native shrub was used in the model.

\subsection{Sheep Flock Structure and Dynamics}

The sheep flock and beef herd classes and structure used in the HCM by [25] were retained in the current model. Beef herd size was held constant in both the base and current model (Section 2.9) and only the sheep flock size was affected by land use change from pasture to native shrubs on the steep slope portions of land. The holding of the beef herd data constant has been utilized in previous HCM model studies [24-28,51]. In the current model, sheep flock size was adjusted to values reported for sheep and beef hill country farm (class 4 ) in the East Coast region of the North Island for the production year 2018/2019 [37].

The sheep flock in both the current and the base model was self-replacing with no external sourcing of replacement flock [25]. Flock dynamics in the base model was based on a constant feed supply and thus flock replacement rates $(R)$ were determined by ewe culling rates $(C)$ and deaths $(D)$ for all age groups $(i)$ at a given time $(t)$ [25]. However, in the current model, feed supply varied among native shrubs planting scenarios (Section 2.3), resulting in fluctuating feed balance which, therefore, affected the flock dynamics. Feed balance $(F)$ (Section 2.9) was, therefore, used in addition to ewe culls and deaths to determine flock replacement rates in the current model. The model estimates that a mature ewe requires approximately 6600 megajoules of metabolizable energy (MJ ME) annually $[52,53]$ and this value was used to determine ewe number changes with fluctuations in feed balance with conversion of pasture to native shrubs (i.e., up to $10 \%$ of total farm area over time).

$$
\begin{gathered}
R_{t}=\sum_{i=1}^{I}\left(\left(D_{i}+C_{i}\right)+\left(\operatorname{int}\left(F_{t} / 6600\right)\right)\right) \\
\text { If, }-6600>F_{t}>\text { 6600then } F_{t}=0
\end{gathered}
$$

The lamb flock sizes in both current and base models were dependent on farm feed supply $[24,54]$ and the lamb selling policy in the HCM model was retained.

\subsection{Pasture Growth on Hill Country Farms}

Pasture production on sheep and beef hill country farms is influenced by the slope and aspect, which modifies the microclimate and soil properties of the terrain [6,33], as shown in Table 3. Monthly pasture growth rate estimates for the region for this farm class [55] were used as the average for the low slope class. The percentage difference in pasture production on the medium and steep slopes, relative to low slope, were based on [6] and adjusted to ensure the medium and steep slopes pasture production was $52.1 \%$ and $38.1 \%$ of the low slope, respectively. This was to enable the modelled farm to support flock numbers similar to those for a class 4 hill country farm on the East Coast region of New Zealand [37] 
Table 3. Published percentage of pasture production on medium and steep slopes relative to the low slope and the estimated pasture yields from the three slope classes (low, medium, and steep) on New Zealand North Island sheep and beef hill country farms.

\begin{tabular}{ccccccc}
\hline \multicolumn{2}{c}{$\begin{array}{l}\text { Pasture \% Change Relative to the } \\
\text { Low Slope }\end{array}$} & \multicolumn{3}{c}{$\begin{array}{c}\text { Pasture Yield } \\
\text { (DM kg/ha/y) }\end{array}$} & \multirow{2}{*}{ Source } \\
\cline { 1 - 6 } Low & Medium & Steep & Low & Medium & Steep & \\
\hline 100 & 46.2 & 31.9 & 12,568 & 5806 & 4003 & {$[6]^{1}$} \\
100 & 73.8 & 65.6 & 13,803 & 10,188 & 9050 & {$[9]^{2}$} \\
100 & 81.6 & 61.3 & 15,773 & 12,878 & 9669 & {$[9]^{2}$} \\
100 & 77.2 & 58.0 & 14,072 & 10,857 & 8164 & {$[45]^{2}$} \\
100 & 76.9 & 46.2 & 9425 & 7250 & 4350 & {$[10]^{3}$} \\
\hline
\end{tabular}

Studies marked with ${ }^{1}$ superscript are based on general southern North Island, ${ }^{2}$ on summer moist, and ${ }^{3}$ on Northland sheep and beef hill country farms in New Zealand North Island.

\subsection{Native Shrubs Growth and Herbage Yields}

Several mathematical functions (linear, exponential, logarithmic, logistic, and Gompertz) can be used to estimate growth in native shrubs, but they differ in parameters utilized and growth curve characteristics [56]. Linear regression functions have a constant growth rate while exponential and logarithmic functions assume constant increasing and decreasing rate of growth, respectively [56]. The constant rate of change in linear regressions limits their use in lifespan simulations since plant growth is affected by environmental factors and physiological stages [56]. Logistic functions have a limitation to a radial symmetry on its curve while Gompertz function curves are asymmetrical and, thus, most suitable for plant growth simulations [56,57].

A Gompertz function (Equation (2)) was derived using Eucalyptus saligna (Eucalyptus) Nelder spacing data [58] due to the unavailability of New Zealand native shrubs data. The Gompertz function was based on trees planted at a density of approximately 1000 stems per hectare $(\mathrm{sph})$ and was used to simulate individual stem basal diameter $(B D)$ growth $(\mathrm{cm})$ for 50 years $(t)$. A planting density of approximately 1000 sph was used for the native shrubs; it was common with exotic trees in erosion control on the North Island hill country farms as it achieves canopy closure relatively quickly, thus limiting weed encroachment $[8,19]$, in addition to meeting the canopy cover requirements of $30 \%$ for carbon trading registration in New Zealand [17].

$$
B D=26.221 \exp (-\exp (0.203(t-5.751)))
$$

The estimated $B D$ was used as an allometry in a power function to predict the herbage yield $(H Y)$ in kilogram of dry matter per tree (Equation (3)) and was assumed to consist of leaves and edible stems not exceeding $5 \mathrm{~mm}$ in diameter [15,59].

$$
H Y=0.0284 B D^{2.113}
$$

However, eucalyptus differ in physiognomy and have faster growth rates translating to higher biomass accumulation compared to native shrubs [17]. Biomass accumulation is species specific, finite per unit area, and can be used to estimate optimal foliage biomass for a given species $[17,60]$. Native shrub foliage biomass was assumed to be $6.4 \%$ of the total carbon stock [61-64] and was predicted using the indigenous forest carbon stock per hectare for forests planted after 1990 [17]. Therefore, a feedback loop relating $B D$ and $H Y$ to native shrub foliage biomass was used in the model to adjust the eucalyptus basal diameter growth to that expected for New Zealand native shrubs. The feedback loop delayed $B D$ growth when $H Y$ exceeded the native shrub foliage biomass. The total native shrub herbage production of the farm was a function of the estimated $H Y$, planting density, and the total area annually planted in native shrubs. 


\subsection{Native Shrub Understory Pasture Production}

As the native shrub canopy expands with growth, it reduces understory pasture production by limiting water and photosynthetic light from reaching the ground $[65,66]$. However, the rate of understory pasture reduction is dependent on canopy cover which is commensurate with native shrub density per unit area [66,67]. In the model, the area planted in native shrubs was assumed to consist of both areas under and outside the canopy and therefore differed in pasture production due to canopy cover effects. Native shrub canopy was assumed to have a cylindrical base [68] and the canopy diameter $(C D)$ in meters was used to estimate individual native shrub canopy area $(C A)$ in meters squared (Equation (5)). A linear allometric function (Equation (4)) [69] relating $C D$ to stem basal diameter was used to determine the $C D$ increase with native shrub growth. Total canopy area at a given moment on the area planted in native shrubs was obtained as a function of $C A$ and native shrub density. Canopy cover was estimated using the total canopy area as a percentage of the total area planted in native shrubs. An exponential function (Equation (6)) with an extinction point at $65 \%$ canopy cover was used to estimate understory pasture reduction $(P R)$ as a percentage relative to the open pastures $[65,67]$.

$$
\begin{gathered}
C D=1.966+0.115 \mathrm{BD} \\
C A=\pi(0.5 \times C D)^{2} \\
P R=99.979 \exp (-0.01 C A)
\end{gathered}
$$

The areas not under canopy were assumed to have pasture production the same as steep slope class open pastures. Therefore, total pasture production from the area in native shrubs comprised of the understory pasture and pasture from areas not under canopy.

\subsection{Native Shrubs Carbon Stock}

Precalculated values of carbon stock per hectare for indigenous forest planted after 1990 were used as the annual carbon stock values for native shrubs planted on the modelled farm [17]. The net annual carbon stock accumulation was obtained as the difference between the current and the preceding year. In the model, the age of the native shrubs and annual total area in native shrubs were used to factor the total net carbon stock accumulation [17].

\subsection{Feed Supply, Demand, and Balance}

The total feed supply in megajoule of metabolizable energy (MJ ME) on the modelled farm comprised open pastures and native shrub forage. Open pastures were from the low and medium slopes and the portion of the steep slope without native shrubs (Section 2.5), while native shrub forage included pastures and native shrub fodder from the steep slope portion with native shrubs (Sections 2.6 and 2.7). Open pastures were available for grazing throughout the year for the modelled period. However, native shrub forage was only available five years after planting for each respective native shrub portion of land (Section 2.3) and could only be utilized for a further five years (browsing window). The five-year period between planting native shrubs and the browsing window in each respective native shrub portion of land was assumed to allow the native shrubs to establish and avoid animal induced damage. Further, after the five-year browsing window (10 years after the last planting for each portion), the native shrubs were assumed to have a canopy cover above $65 \%$ which restricted understory pasture growth.

Pasture utilization by sheep was assumed to be approximately $70 \%$, typical of North Island sheep and beef hill country farms [24,52]. Similarly, a 70\% utilization rate was assumed for the accessible native shrubs fodder due to unavailability of native shrub utilization data for New Zealand. However, a native shrub height increase with age was assumed to affect fodder available to sheep. Native shrub height increase $(H)$ in meters with time was predicted with a power function allometry (Equation (7)) using native shrub 
$B D$. Sheep can reach browse to heights of $1.17 \mathrm{~m}[70,71]$ with increasing heights reducing the accessible browse. In the model, sheep browsed the native shrubs fully to a height of 0.87 [70] after which available browse $(A B)$ reduced logarithmically (Equation (8)) to no access when the total native shrub height reached $5.0 \mathrm{~m}$. At the total native shrub height of $5 \mathrm{~m}$, the accessible edible foliage below $1.17 \mathrm{~m}$ was assumed to be limited due to self-pruning of lower branches due to shading effect from canopy closure [72].

$$
\begin{gathered}
H=0.1976 B D^{1.1436} \\
A B=-0.516 \ln (H)+0.8839
\end{gathered}
$$

where $A B=1$ if $H<0.87$ and $A B=0$ if $H>5$.

Annual feed demand was estimated using approximations of feed requirements for each sheep class (Section 2.4) [25] and the difference with feed supply was taken as the farm feed balance. The beef cattle herd was held constant and thus beef cattle feed demand in both the base model and the current model were constant over the modelled period. The approach of holding the beef feed demand constant has been used previously with the bioeconomic model $[24,25,27,73]$.

\subsection{Farm Economics}

The steep slope portion on sheep and beef hill country farms are commonly grazed by sheep and converting part of this portion of land to native shrub was assumed to affect the sheep carrying capacity rather than the beef herd. Hence, the beef enterprise income and costs on a per hectare basis were assumed to be unaffected in the economic assessment, which included discounted net cash flow in terms of cash operating surplus (COS), net present value (NPV), internal rate of return (IRR), and break-even analysis. Two native shrub planting rates (10\% and $20 \%$ ) were compared to a base scenario without native shrubs ( $0 \%$ native shrubs) at three discount rates $(5 \%, 7 \%$, and $10 \%)$ for 50 years. The COS for the sheep enterprise and sheep enterprise with native shrub was obtained as the difference between cash income and cash operating expenses. Sheep enterprise COS estimation followed the previously used [25] approach, while native shrub enterprise COS was derived using cash inflow from carbon trade and cash outflow from expenses associated with pre-planting, planting, and post planting costs. The current two-year average of NZD 32/NZU (New Zealand Emission Unit) [74] was used as the carbon price in the current model. The NPV (Equation (9)) was used to assess the total value of planting native shrubs at the two planting rates vis a vis not planting.

$$
N P V=\sum_{t=0}^{n} \frac{R_{t}}{(1+\rho)^{t}}
$$

where $R$ is net cash flow in New Zealand dollars (NZD) at time $t, \rho$ is the discounting rate, and $n=50$ is the investment duration.

Annual IRR for planting native shrubs at different rates was estimated by determining the discounting rate at which $N P V$ was equivalent to zero. A break-even analysis was also undertaken to estimate the carbon price at which the NPV for the native shrub-inclusive model equaled the base (no-native shrub) model.

\section{Results and Discussion}

The results comparing the impacts of up to $10 \%$ of the modelled farm in native shrubs on farm feed supply, sheep flock dynamics, and farm economics are discussed in the following sections. 


\subsection{Feed Supply}

Figure 2 shows the annual feed supply for annual shrub planting rates of $0 \%$ (base model), $10 \%$, and $20 \%$ per year over $10 \%$ of the farm for 50 years. Annual feed supply in MJ ME remained constant for $0 \%$ native shrubs but had a staggered decrease in the $10 \%$ and $20 \%$ native shrub planting rates before levelling off after 16 and 14 years, respectively. The initial decrease was highest in the $20 \%$ planting rate due to the greater areas being removed per year from grazing. The long-term reduction in annual feed supply for both planting regimes (21.46 million MJ ME) compared to the base model (23.23 million MJ ME) was $7.6 \%$. The long-term feed supply reduction was the same for both planting rates due to the consistent $10 \%$ reduction in grazing area, post the transition periods, and resulted in lower but varying mean annual feed supply for the planting rates regimes relative to base model.

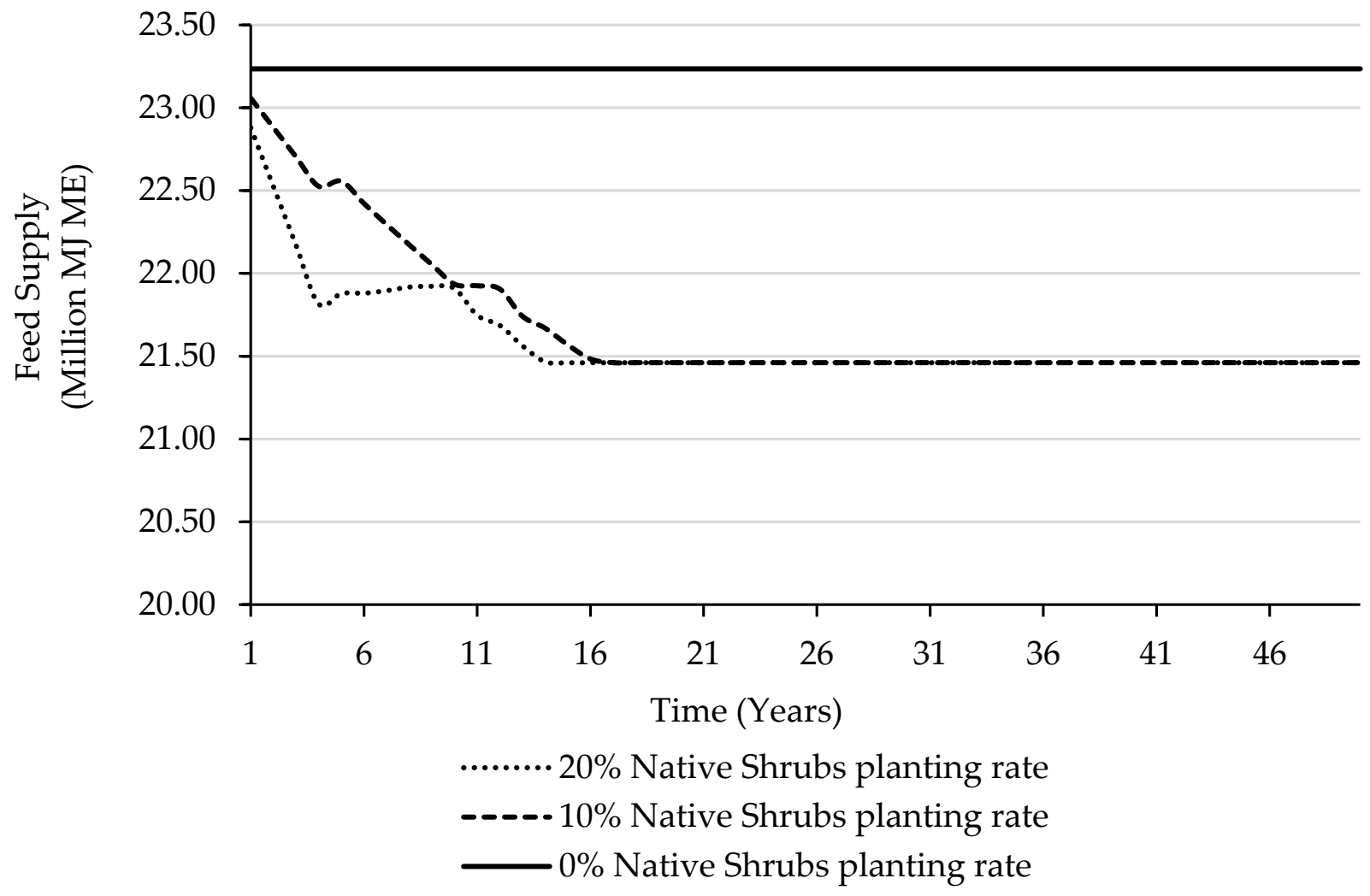

Figure 2. Annual feed supply for 50 years in metabolizable energy (million megajoules) with native shrubs planted on $10 \%$ the modelled farm at three planting rates $(0 \%, 10 \%$, and $20 \%$ per year).

The lower mean annual feed supply for the $10 \%$ and $20 \%$ planting rates, compared to the $0 \%$ rate, was due to a reduction in pasture production area on the steep slopes and the restricted period of browsing for the shrubs between years 5 and 10 post planting. However, the mean reduced annual feed supply, overall, for the $10 \%$ and $20 \%$ planting rates, compared to the base model (Table 4), was proportionately less than might be expected. This can be attributed to the low pasture production on steep slopes compared to the easier slopes $[6,9,10]$. 
Table 4. Total mean farm annual feed supply in metabolizable energy (million megajoules) for the modelled farm based on low, medium, and steep slope types with shrubs planted on $10 \%$ of the farm at three planting rates $(0 \%, 10 \%$, and $20 \%)$ per year, and corresponding mean annual feed allocation to sheep and beef cattle.

\begin{tabular}{|c|c|c|c|c|c|c|c|c|}
\hline \multirow{2}{*}{$\begin{array}{l}\text { Planting } \\
\text { Rate (\%) }\end{array}$} & \multicolumn{3}{|c|}{ Slope Category Mean Annual Feed Supply } & \multirow{2}{*}{$\begin{array}{c}\text { Total Farm Mean } \\
\text { Annual Feed Supply }\end{array}$} & \multicolumn{2}{|c|}{ Feed Supply to Sheep } & \multicolumn{2}{|c|}{ Feed Supply to Bee } \\
\hline & Low & Medium & Steep & & Feed & $\%$ & Feed & $\%$ \\
\hline 0 & 4.05 & 11.13 & 8.05 & 23.23 & 13.94 & 60.0 & 9.29 & 40.0 \\
\hline 10 & 4.05 & 11.13 & 6.51 & 21.69 & 12.40 & 57.2 & 9.29 & 42.8 \\
\hline 20 & 4.05 & 11.13 & 6.41 & 21.59 & 12.30 & 57.0 & 9.29 & 43.0 \\
\hline
\end{tabular}

Comparatively, the mean annual feed supply for the base model when converted from MJ ME to dry matter kilograms per hectare (DM kg/ha/y) for the low $(11,700 \mathrm{DM}$ $\mathrm{kg} / \mathrm{ha} / \mathrm{y}$ ), medium (6140 DM kg/ha/y), and steep slope (4490 DM kg/ha/y) was within the ranges reported for North Island hill country sheep and beef cattle farms in New Zealand $[6,9,10,45]$. This indicates the model adequately represented the current state of the North Island hill country sheep and beef cattle farms feed supply, before the introduction of native shrubs on portions of the steep slopes.

Beef cattle were allocated a constant feed supply of the modelled total mean annual farm feed supply with the remainder utilized by sheep. The reduction in annual mean farm feed supply with conversion of pastures to native shrubs resulted in a greater proportion of feed allocated to beef cattle for the planting rates, compared to the $0 \%$ native shrubs, to maintain a constant feed supply to the beef cattle herd. The fluctuations in the feed supply proportions for the beef cattle herd and sheep flock are common in the hill country sheep and beef cattle farms with adjustment of the farm stock sizes to meet the feed supply $[26,28,75]$. Feed supply for the beef cattle was from the open pastures and only sheep browsed the native shrub areas due to the potential for cattle to excessively damage the shrubs. The bulk of the shrub area forage was from understory pasture rather than the shrub fodder (Figure 3). Accessible fodder was assumed to be directly harvested by sheep, whereas with mature willows and poplar fodder is available only after pollarding or coppicing $[15,76]$. The low feed supply from shrub fodder and changes over time can be attributed to reduced access as the shrubs increased in height $[70,77,78]$.

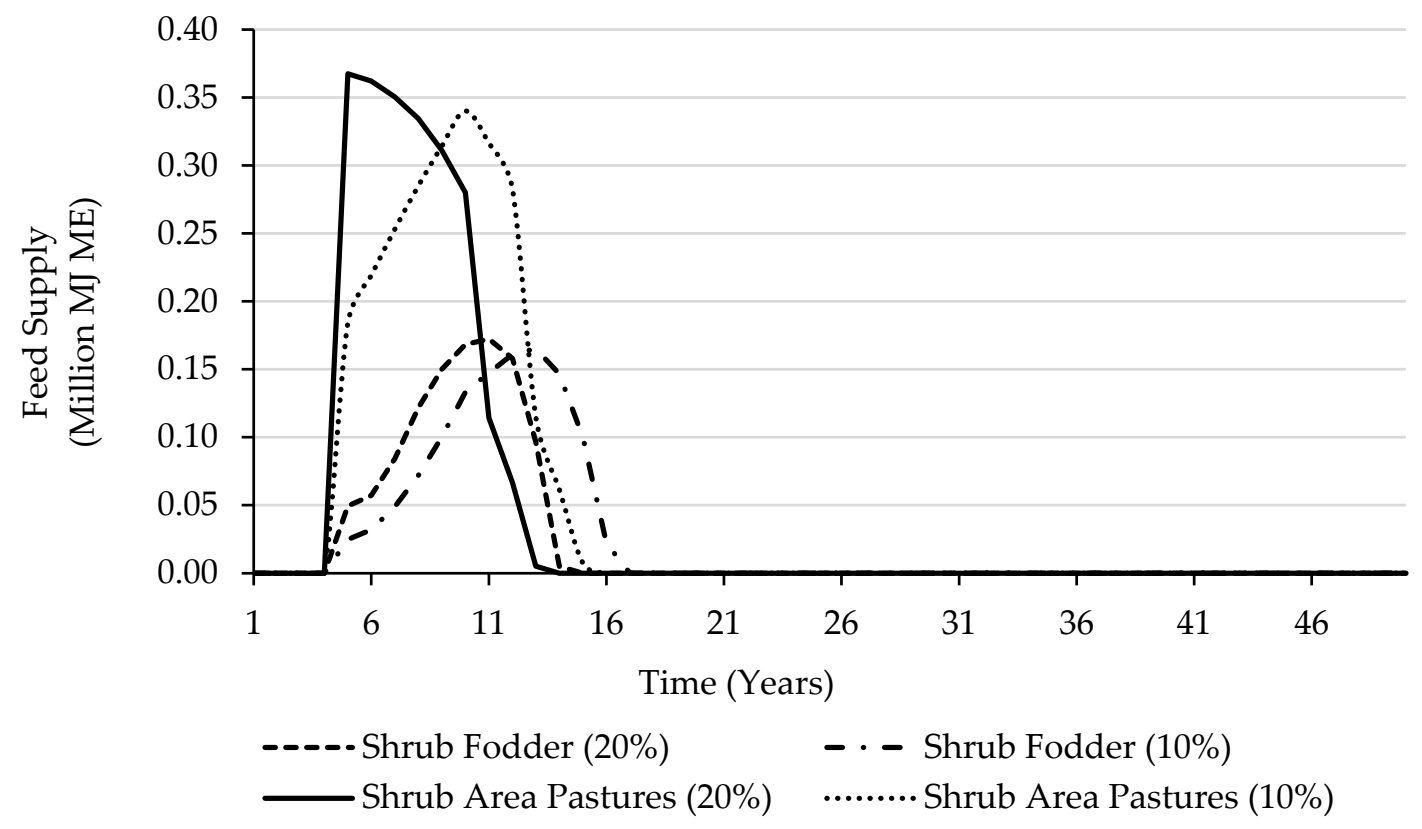

Figure 3. Total shrub forage (shrub fodder, understory, and open pastures) in metabolizable energy (million megajoules) per year for 50 years, on $10 \%$ of the modelled farm planted in native shrubs at $10 \%$ and $20 \%$ per year planting rates. 
Mean pasture feed supply on slopes planted with shrub was higher for the $10 \%$ planting rate than the $20 \%$ planting rate, but mean shrub fodder was not greatly affected by shrub planting rate. The higher mean pasture feed supply for the $10 \%$ native shrub planting rate compared to the $20 \%$ planting rate resulted from less land converted annually to native shrubs and, therefore, sheep had longer cumulative feed supply from open and understory pastures compared to the $20 \%$ planting rate on the shrub area. The similar native mean shrub fodder over the 50 years for the $10 \%$ and $20 \%$ native shrub planting rates can be explained by the fact that an equal number of native shrubs were planted over time (1000 stems per hectare) for each planting rate on a cumulatively equal portion of the steep slope (up to $10 \%$ of the modelled farm) and were browsed for a similar duration (five years).

\subsection{Flock Dynamics}

Flock size differed (Figure 4) with changes in feed supply with different native shrub planting rates. Mean annual flock size remained uniform at 2747 sheep over the modelled period for the base model ( $0 \%$ native shrub) but reduced by $10.9 \%$ and $11.6 \%$ (mean) for the $10 \%$ and $20 \%$ planting rates, respectively. The decrease in flock size for these scenarios was achieved by reducing the number of replacement ewe lambs entering the flock and, therefore, selling more lambs rather than culling the ewe flock. Reducing flock size by preference of culling older ewes has been shown to reduce flock meat production and ewe reproductive performance, which peaks at five years of age $[25,26]$. Therefore, it was decided to avoid these potential negative effects.

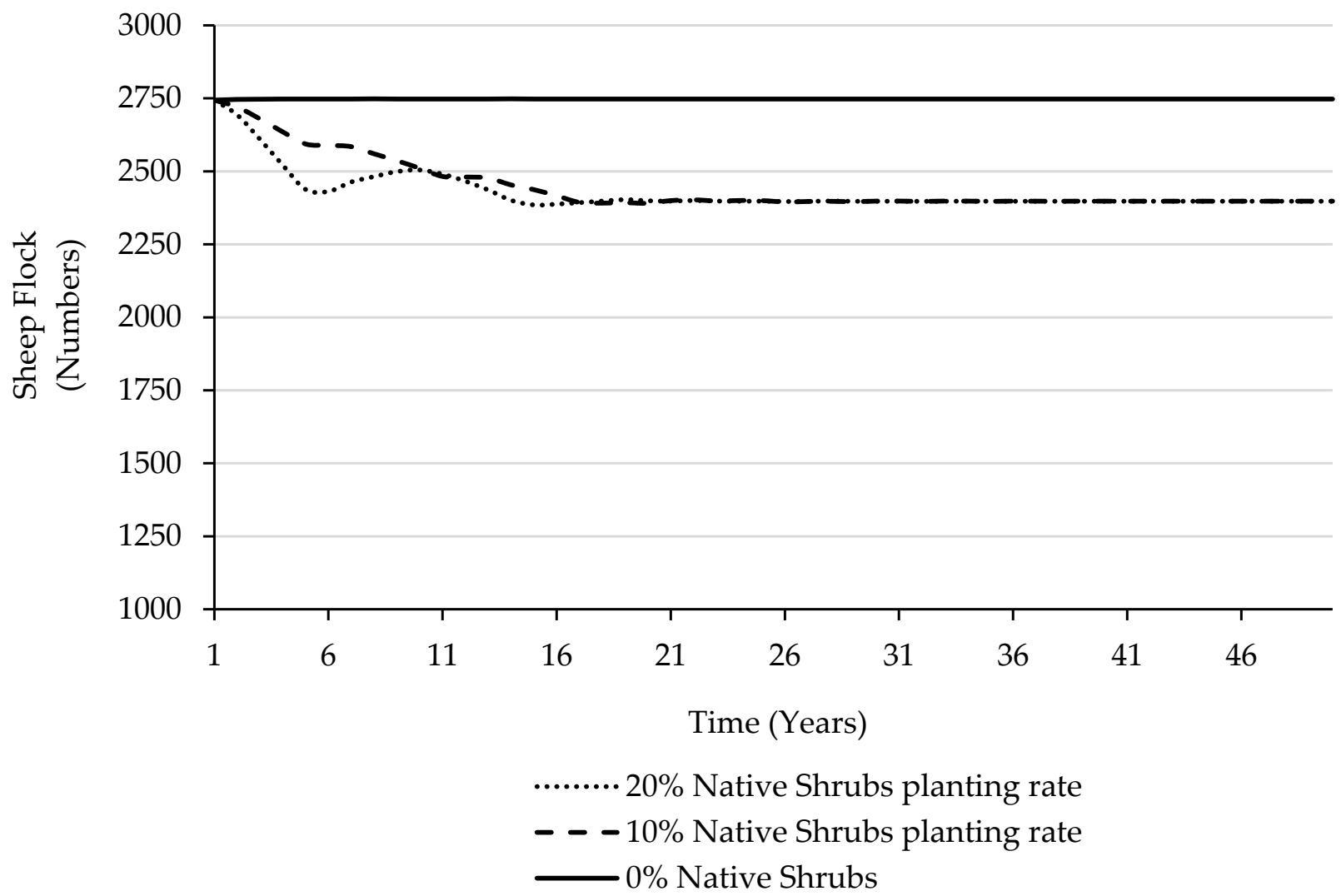

Figure 4. Fluctuation in sheep flock size with native shrubs planted on $10 \%$ of the modelled farm at $0 \%, 10 \%$, and $20 \%$ planting rates per year, over 50 years.

In scenarios with planting of native shrubs there was a decrease in flock size for initial five years which was followed by flock size fluctuations, for both the planting rates. The initial constant decrease in flock size was due to decrease in feed supply from land being 
withdrawn from grazing without compensatory feed supply, while the fluctuations resulted from the sequential opening and closure of the browsing window for the consecutive portions planted in native shrubs. Overall flock size on the modelled farm stabilized after 17 and 15 years for the $10 \%$ and $20 \%$ planting rates, respectively, across the 50 years modelled. This corresponded to 7 and 10 years after the last planting for the $10 \%$ and $20 \%$ planting rates, respectively. The long flock stabilization period for the $20 \%$ planting rate compared to $10 \%$ was due to a greater total feed decrease and thus lower replacement ewe lambs retained during the native shrubs establishment period (10 and 5 years for $10 \%$ and $20 \%$ planting rates, respectively). Low replacement ewe lamb rates resulted in a gradual transient decrease in ewe flock size along the ewe flock age classes affecting the long term flock reproductive performance $[25,26]$, combining to produce prolonged flock size fluctuations. However, the long flock stabilization periods are unlikely to be experienced on most farms because flock size management is typically based on short-term forecasted feed supply [75], whereas in the model current annual feed supply determined flock size.

The overall flock structure, across time, was similar in all native shrub planting rates and comprised of $78.7 \%$ mixed age ewes, $20.0 \%$ replacement ewe lambs, and $1.3 \%$ other sheep. The flock structure for the modelled farm was similar to the average sheep flock structure on the North Island sheep and beef farms [37]. The consistency in flock structure over the modelled period and scenarios indicates that the model regulated flock dynamics based on the modelled farm annual feed supply.

\subsection{Farm Economic Analysis of Establishing Native Shrubs}

Economic analyses in agricultural enterprises provide means for choosing among alternative investment opportunities based on their broad sustainability and projected financial viability [79]. Sheep and beef cattle are the major enterprises in the New Zealand hill country sheep and beef cattle farms and their economic worth have been widely studied $[5,27,80,81]$. However, native shrubs are gaining interest as alternative complementary investment on hill country sheep and beef cattle farms, but their economic value within the farm system is currently anecdotal [19].

The modelled farm economic analysis undertaken focused on the sheep enterprise because it was assumed that investing in native shrubs on $10 \%$ of the farm only affected sheep feed supply, hence flock size causing changes in sheep enterprise cashflow. In the model, capital used to invest in the establishment and maintenance of the native shrubs was sourced internally from the sheep enterprise proceeds. Therefore, the sheep enterprise in the modelled farm comprised of cashflows from the established sheep flock enterprise and the native shrub investment.

Cashflows were discounted to forecast, over a 50-year period, the financial performance of the modelled native-shrub planting scenarios. Discounting cashflows is merited to account for the time value of money associated with investments [24,82]. Annual net cashflows expressed as cash operating surplus (COS) were discounted at $7 \%$, which is the rate used in cost benefit analysis of public investments and evaluation of small forestry projects in New Zealand [83]. Net present value (NPV) and break-even analysis were evaluated at three discount rates of $5 \%, 7 \%$, and $10 \%$. The discount rates range considered uncertainties in discount rates with time as observed over the years with the business lending rates in New Zealand [84].

\subsubsection{Sheep Enterprise Discounted Cash Operating Surplus from the Sheep Flock}

The number of lambs sold from the sheep flock annually were the main drivers of the sheep enterprise COS. The $0 \%$ native shrub had a constant discounted sheep enterprise COS which decreased smoothly and was above that for $10 \%$ and $20 \%$ planting rates except in the initial five years of native shrub planting phase (Figure 5). The gradual drop in feed supply with withdrawal of land from grazing during the initial five years caused more replacement ewe lambs to be sold, which led to a higher sheep enterprise COS for the 10 
and $20 \%$ planting rates than for $0 \%$ native shrubs but was higher for the $20 \%$ than the $10 \%$ planting rate. Sale of replacement ewe lambs in the initial five years led to a gradual decline in flock size across the age classes and was higher for $20 \%$ rather than the $10 \%$ planting rate. The decline in flock size resulted in fewer lambs born and therefore sold, which explains the lower sheep enterprise COS for the two planting rates compared to $0 \%$ native shrubs, but which was higher for the $10 \%$ compared to $20 \%$ planting rate. The total withdrawal of $10 \%$ of the land from grazing (after 20 and 15 years for $10 \%$ and $20 \%$ planting rates, respectively) led to a decrease in flock size and thus the lambs sold, explaining the observed marginal lower sheep enterprise COS for the two planting rates compared to the $0 \%$ native shrubs. Adjustment of flock size to meet the farm feed supply is a routine farm planning activity in the hill country sheep and beef cattle farms and affects farm annual sheep enterprise COS [75].

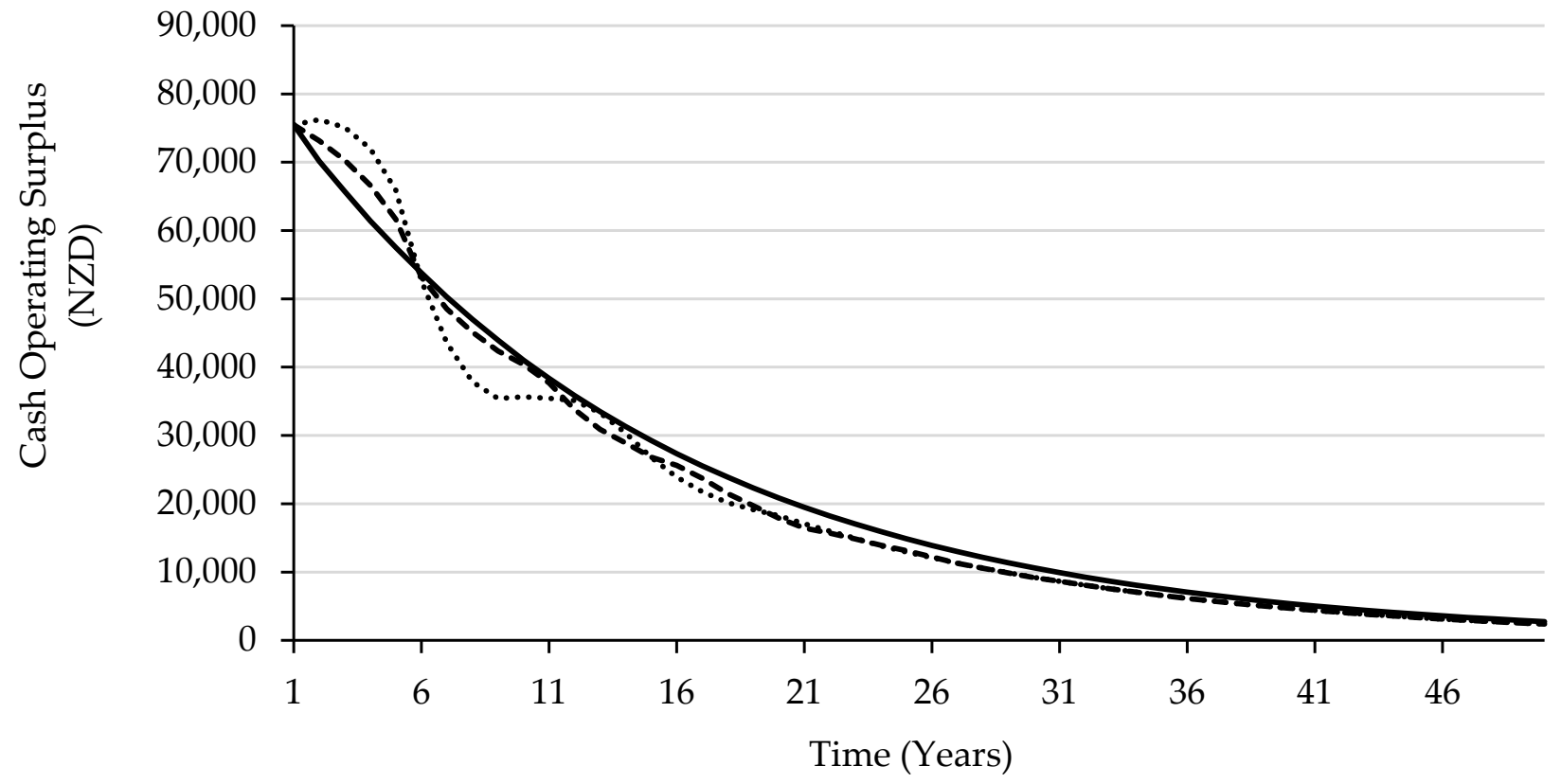

\section{….... 20\% Annual native shrubs planting rate \\ ----. 10\% Annual native shrubs planting rate \\ $0 \%$ Native shrubs}

Figure 5. Annual sheep flock cash operating surplus (COS) discounted at $7 \%$ per year over 50 years for native shrubs planted on $10 \%$ of the modelled farm at $0 \%, 10 \%$, and $20 \%$ planting rates per year.

The conversion of $10 \%$ of the land to native shrub led to an overall higher mean annual sheep enterprise COS for the $0 \%$ native shrubs (NZD 22,270) scenario compared to the planting rates. Mean annual sheep enterprise COS was higher for the 10\% (NZD 21,368) than $20 \%$ (NZD 21,199) planting rate. Combined, this data indicates that conversion of the $10 \%$ of the modelled farm to native shrubs led to a decrease in sheep enterprise COS, explained by the reduction in overall flock size across time. A decline in sheep enterprise COS have been reported in New Zealand due to declining flock sizes as result of converting portions of hill country sheep and beef cattle farms to other farming enterprises, such as dairy cattle, deer, plantation forestry, and subdivision into smaller lifestyle blocks since the 1990s [1,36]. However, a greater decline in sheep enterprise COS would be expected to occur when more productive low and medium slope land portions are withdrawn from sheep farming for other agricultural enterprises, compared to the non-utilizable steep slopes, due to their higher flock carrying capacity $[1,36]$. In these modelled scenarios, steep slope areas were removed and planted in native shrubs. 


\subsubsection{Carbon Income and Native Shrub Expenses}

Discounted carbon income initially increased steadily and peaked at 10 and 12 years for the $10 \%$ and $20 \%$ planting rates, respectively, before gradually declining over the modelled period (Figure 6). The steady increase in carbon income over the initial time period resulted from the mean annual increase in the number of native shrubs planted and carbon accumulation, while the gradual decline was due to decreasing mean carbon accumulation with native shrub age [17]. Mean annual carbon income was marginally $(1.17 \%$ ) higher for the $20 \%$ (NZD 3249) compared to the 10\% (NZD 3211) planting rates and can be attributed to higher carbon income for the first 8 years for the $20 \%$ native shrub planting rate due to a both a greater number of, and area planted in, native shrubs at that time. Similarly, mean annual native shrub establishment and maintenance expenses were $21 \%$ higher for the 20\% (NZD 4915) than 10\% (NZD 4056) planting rate due to the higher cost of establishment in the first five years for the $20 \%$ rate, but which were distributed over 10 years for the $10 \%$ planting rate. Overall, the establishment of native shrubs on $10 \%$ of the area of the modelled farm using either $10 \%$ or $20 \%$ native shrub planting rates per year had higher expenses relative to income. This suggests that the modelled carbon price (NZD32/NZU) was too low to offset the costs associated with planting native shrubs.

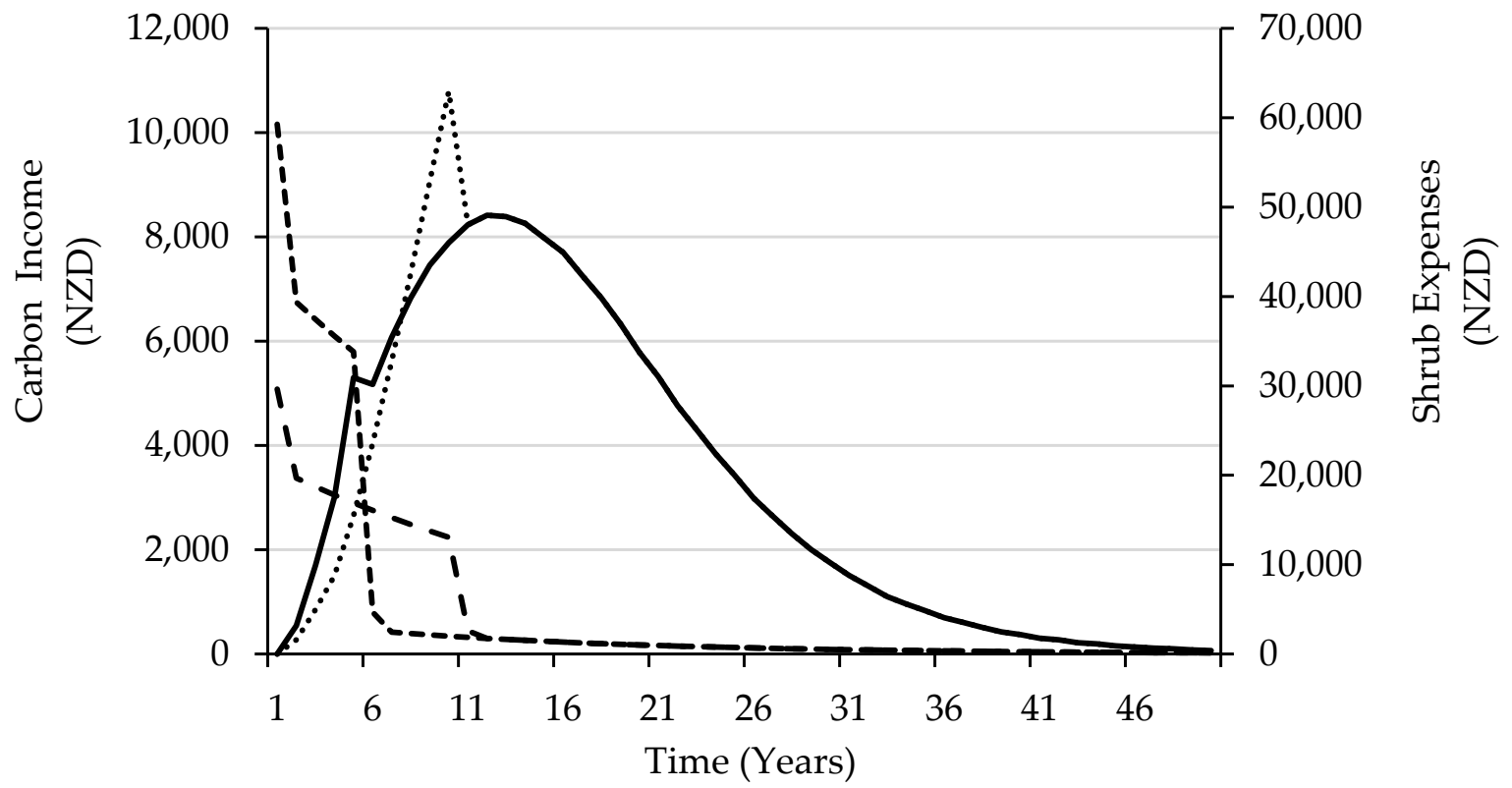

$-20 \%$ Annual native shrubs planting rate carbon income ........ 10\% Annual native shrubs planting rate carbon income - - - $20 \%$ Annual native shrubs planting rate expenses - $-10 \%$ Annual native shrubs planting rate expenses

Figure 6. Total native shrub expenses and carbon income discounted at $7 \%$ per year over 50 years with native shrubs planted on $10 \%$ of the modelled farm at $0 \%, 10 \%$, and $20 \%$ planting rates per year.

\subsubsection{Combined Sheep Enterprise Discounted Cash Operating Surplus}

Total sheep enterprise (combined sheep flock and native shrub) COS for the different native shrub planting scenarios are shown in Figure 7. A constant COS of the sheep-only enterprise (Section 3.3.1) for the $0 \%$ native shrub was maintained, as would be expected, since the cashflow was unaffected by planting native shrubs. However, the reductions in sheep-only enterprise COS coupled with high planting expenses for the native shrubs led to a lower total sheep enterprise COS for the $10 \%$ and $20 \%$ planting rates in the initial 10 and 9 years, respectively, compared to the $0 \%$ native shrubs. However, the total sheep enterprise $\operatorname{COS}$ for the planting rates exceeded that of $0 \%$ native shrubs when the cash 
income from carbon trade exceeded the shrub expenses (between 9 to 31 years and 10 to 31 years for the $20 \%$ and $10 \%$ planting rates, respectively) and after 32 years there were marginal differences among the planting rate scenarios. Overall, mean annual total sheep enterprises COS for $0 \%$ native shrubs (NZD 22,270) was higher by $7.9 \%$ and $12.3 \%$ than that for 10\% (NZD 20,522) and 20\% (NZD 19,532) planting rates, respectively. However, comparing sheep-only enterprise and total sheep enterprise COS for the planting rates revealed that native shrub expenses caused a decrease in the total sheep enterprise mean annual COS by $4.0 \%$ (NZD 21,368 vs. NZD 20,522) and 7.9\% (NZD 21,199 vs. NZD 19,532) for $10 \%$ and $20 \%$ planting rates, respectively. High initial expenses mainly associated with seedling costs have been indicated as a prohibitive factor to the establishment of native shrubs on hill country farms in New Zealand $[19,85,86]$. Although not explored in this study, grants supporting establishment of native shrubs in New Zealand can be used to offset the high initial cost of native shrubs establishment $[19,87,88]$, which may have an impact on the total sheep enterprise COS.

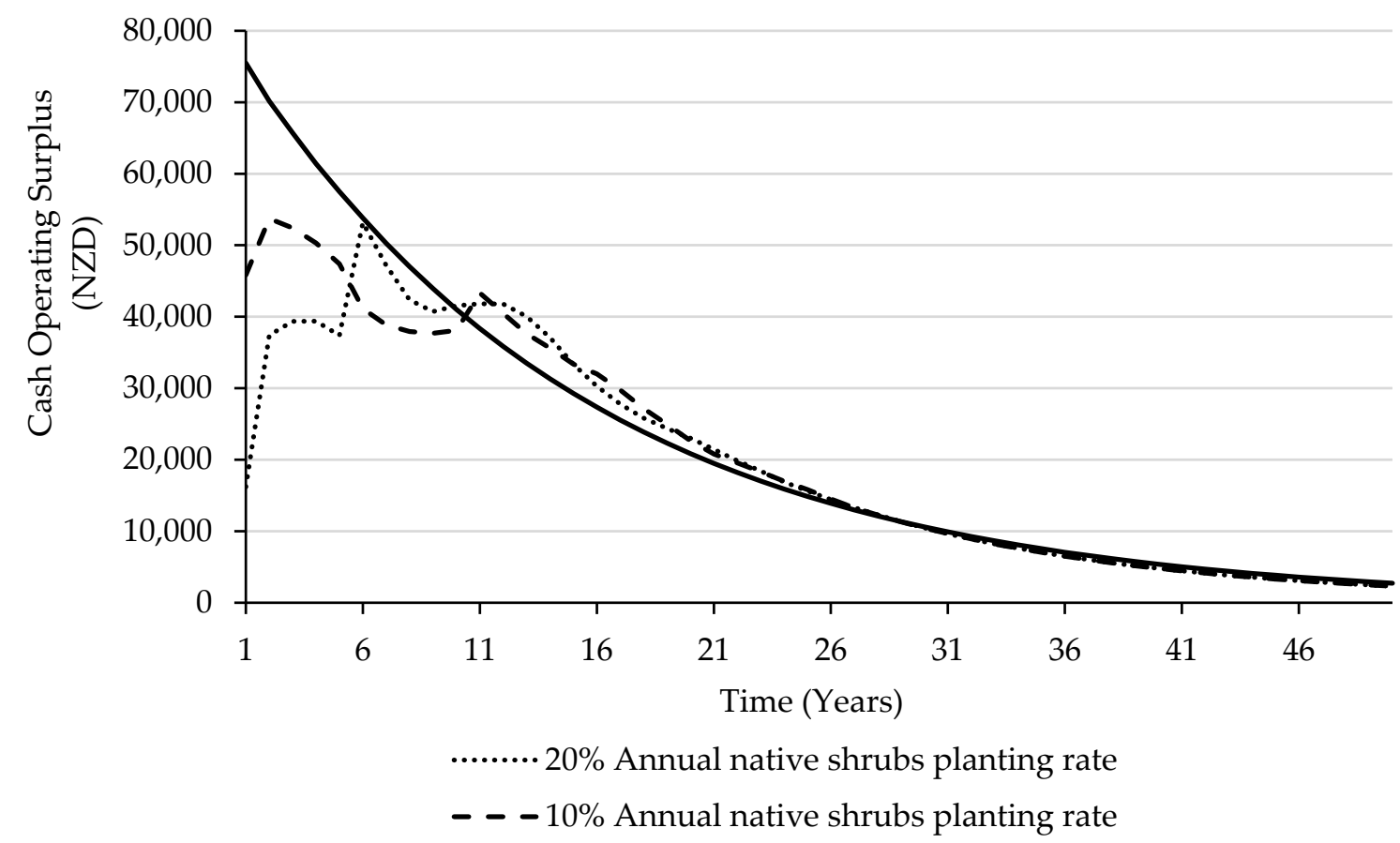

Figure 7. Annual sheep enterprise cash operating surplus (COS) discounted at $7 \%$ per year over 50 years for native shrubs planted on $10 \%$ of the modelled farm at $0 \%, 10 \%$, and $20 \%$ planting rates per year.

\subsubsection{Sheep Enterprise Net Present Value (NPV) and Internal Rate of Return (IRR)}

The NPV decreased with an increase in the COS discount rate (Table 5), an expected outcome owing to their inverse relationship [79,82]. NPV was highest for the $0 \%$ native shrub compared to the planting rates but remained positive even at the very high discounting rate in all the modelled scenarios. Although a positive NPV signifies profitability in an investment in the long run [79], the lower NPVs for the planting rates indicated that investing in the native shrubs on $10 \%$ of the farm at the modelled carbon market (NZD $32 / \mathrm{NZU}$ ) would result in reduction in the sheep enterprise income. This can be explained by the observed drop in sheep flock cash inflow (Section 3.3.1) due to reduction in flock size and the high cash outflow due to native shrub establishment costs (Section 3.3.2) observed for the two planting rates.

However, only cashflows relating to carbon trade were considered in the model, despite native shrubs having other monetary and non-monetary benefits [89]. In addition, $N P V$ assesses the financial profitability and viability of an investment using forecasted cashflows and does not consider non-monetary benefits that may arise over time [79]. 
Some potential non-monetary benefits from the planting of native shrubs on the farm can include, appreciating farm market value, reduction in erosion costs, biodiversity enhancement, landscape aesthetics, restoration of cultural values, and climate change mitigation through carbon sequestration $[19,81,85,89,90]$. Further, the use of a single discount rate in the model assumes that the current agricultural policies and market would prevail unchanged throughout the modelled period. However, agricultural production can change with advancement in technology, consumer preferences, and local and international market fluctuations which affect enterprises cashflows and therefore discount rates on capital [91,92]. In New Zealand, the sheep population has been in decline due to the emergence of other agricultural enterprises, while the meat and wool market trends have fluctuated over time due to reliance on export market and changes in policies locally and internationally [91-93]. Although the two planting rates had lower NPV, the non-monetary value of native shrubs may outweigh those for the $0 \%$ native shrubs and requires further exploration.

Table 5. Net present value in New Zealand dollars (NZD) at three discount rates $(5 \%, 7 \%$, and $10 \%)$ for the sheep enterprise with native shrubs planted on up to $10 \%$ of the modelled farm on the steep slopes at $0 \%, 10 \%$, and $20 \%$ planting rates.

\begin{tabular}{ccccc}
\hline \multirow{2}{*}{ Planting Rate (\%) } & \multicolumn{4}{c}{ Discount Rate (\%) } \\
\cline { 2 - 5 } & $\mathbf{5}$ & $\mathbf{7}$ & $\mathbf{1 0}$ & $\mathbf{5 0}^{\mathbf{1}}$ \\
\hline 0 & $1,546,937$ & $1,191,563$ & 879,919 & 241,951 \\
10 & $1,423,384$ & $1,072,865$ & 764,458 & 167,786 \\
20 & $1,342,444$ & 991,635 & 683,174 & 100,157 \\
\hline
\end{tabular}

${ }^{1}$ This discount rate was used to show NPV did not approach zero even at high values.

The internal rate of return (IRR) is the measure of profitability, which shows the rate at which an investment pays back to its capital [94], and was similar and approached infinity for all native shrub planting rates scenarios. This would be expected since there were no negative cashflows [95] and no external source of capital was borrowed [82] to establish the native shrubs. Therefore, IRR could not be used to compare the native shrub planting regimes due to this limitation.

\subsubsection{Break Even Analysis for Native Shrub Investment on the Model Farm}

The carbon price required to obtain income equivalent to the status quo with $0 \%$ native shrub invested on $10 \%$ of the modelled farm increased with increasing discount rate and native shrubs annual planting rates (Table 6). Overall, the break-even carbon price was higher than the modelled carbon price (NZD 32/ NZU) for the native shrubs annual planting rate at all discount rates. This suggests that even with the modelled lowest return to capital of $5 \%$, investing in native shrubs based on the modelled condition would not be financially attractive to hill country sheep and beef farms. However, [37] estimates a return to capital rate of $2.3 \%$ for investments in the East Coast region hill country (class 4) sheep and beef farm. Although not included in the study, running the model at a $2.3 \%$ discount rates resulted in break-even carbon market of NZD 44.90 and NZD 51.95 for the $10 \%$ and $20 \%$ planting rates, respectively. This further implies that the modelled carbon market price (NZD 32/NZU) was still too low for farms investing in native shrubs on $10 \%$ of their land to financially break-even.

Increasing carbon price to above NZD 25 was suggested as an incentive for afforestation of the hill and hard hill country using radiata pine [96]. However, radiata pine has nearly twice the carbon sequestration potential and, therefore, higher carbon income compared to the native shrubs [17]. In addition, radiata pine has additional cash inflow from logs and lower establishment costs [85,89] and, therefore, would have a lower break-even carbon price compared to native shrubs based on monetary benefits [97]. High costs in native shrubs establishment can be averted by allowing natural revegetation. However, this attracts higher risk of pest and weeds invasion that could affect survival of the juvenile 
native shrubs $[19,89]$ and would take substantially longer to occur. Suggested potential interventions that could enable hill country farms that are planting native shrubs to breakeven include, setting a premium native vegetation carbon price, upfront native vegetation establishment financing, and providing grants for establishing native vegetation [89].

Table 6. Break-even carbon price in New Zealand dollars per New Zealand unit (NZD/NZU) of carbon at three discount rates $(5 \%, 7 \%$, and $10 \%)$ for planting native shrubs on $10 \%$ of the modelled farm at $10 \%$ and $20 \%$ planting rates per year.

\begin{tabular}{cccc}
\hline \multirow{2}{*}{ Planting Rate (\%) } & \multicolumn{3}{c}{ Discount Rate (\%) } \\
\cline { 2 - 4 } & $\mathbf{5}$ & $\mathbf{7}$ & $\mathbf{1 0}$ \\
\hline 10 & 49.90 & 55.67 & 67.50 \\
20 & 61.30 & 71.41 & 91.24 \\
\hline
\end{tabular}

\section{Conclusions}

The study revealed that addition of a native shrub sub-model to the established hill country sheep and beef enterprise model enabled partitioning of the archetype farm into the major slope types and their respective herbage productivity. Planting native shrubs on $10 \%$ of the farm on the steep slope caused a disproportionate decrease in overall mean annual farm feed supply by $6.6 \%$ and $7.1 \%$ for $20 \%$ and $10 \%$ planting rates, respectively, relative to the $0 \%$ native shrub. The reduction in feed supply resulted in a $10.9 \%$ and $11.6 \%$ reduction in sheep flock size, which caused a decrease in sheep-only enterprise cash operating surplus by $4.1 \%$ and $4.8 \%$ for the $10 \%$ and $20 \%$ planting rates, respectively, compared to $0 \%$ native shrubs. There were no greater differences in carbon income among the planting rates, but the native shrubs expenses were higher by $20 \%$ for $20 \%$ compared to the $10 \%$ planting rate. Overall, native shrub expenses were higher than carbon income and caused a further $4.0 \%$ and $7.9 \%$ reduction in the total sheep enterprise cash operating surplus for $10 \%$ and $20 \%$ planting rates, respectively. The net present value for all scenarios was positive and was higher for $0 \%$ native shrubs and least for $20 \%$ planting rate. Breakeven carbon prices were higher than the modelled carbon price, indicating that a higher carbon price above the break-even price can make planting native shrub attractive to the hill country sheep and beef cattle farms. The rapidly changing value of the carbon price can be easily assessed using the model.

Author Contributions: Conceptualization, J.C.W., P.R.K., P.R.T., J.P.M. and S.J.P.; methodology, J.C.W. and P.R.T.; model results review and validation, J.C.W., P.R.K., P.R.T., J.P.M. and S.J.P.; writingoriginal draft preparation, J.C.W.; writing-review and editing, P.R.K., P.R.T., J.P.M. and S.J.P.; supervision, P.R.K., P.R.T., J.P.M. and S.J.P. All authors have read and agreed to the published version of the manuscript.

Funding: This research was funded by Hill Country Futures Partnership Programme (BLNZT1701Beef + Lamb New Zealand, Ministry of Business, Innovation and Employment [MBIE], Seed Force New Zealand and PGG Wrightson Seeds), and C Alma Baker Trust. The corresponding author studies are funded by the Ministry of Foreign Affairs and Trade through New Zealand Scholarship.

Institutional Review Board Statement: Not applicable.

Acknowledgments: The authors acknowledge Lydia Jane Farrell for the support in the use of STELLA Architect software, providing the base model, and continued guidance in the development of the native shrub model.

Conflicts of Interest: The authors declare no conflict of interest. 


\section{References}

1. Morris, S.T.; Kenyon, P.R. Intensive sheep and beef production from pasture-A New Zealand perspective of concerns, opportunities and challenges. Meat Sci. 2014, 98, 330-335. [CrossRef] [PubMed]

2. Beef+Lamb NZ. Farm Facts: Compendium of New Zealand 2020, 44th ed.; Beef + Lamb New Zealand: Wellington, New Zealand, 2020.

3. StatsNZ Agricultural Production Statistics: June 2020 (Final). Available online: https:/ /www.stats.govt.nz/indicators/livestocknumbers (accessed on 9 March 2020).

4. Beef+Lamb NZ. Stock Number Survey as at 30 June 2020; Beef + Lamb New Zealand: Wellington, New Zealand, 2020.

5. Beef+Lamb NZ. Fact Sheet: Hill Country Sheep and Beef Farms; Beef + Lamb New Zealand: Wellington, New Zealand, 2020.

6. Kemp, P.D.; Lopez, I.F. Hill Country Pastures in the Southern North Island of New Zealand: An Overview. Hill Ctry.-Grassl. Res. Pract. Ser. 2016, 16, 289-298.

7. Hodgson, J.; Cameron, K.; Clark, D.; Condron, L.; Fraser, T.; Hedley, M.; Kemp, P.D.; Lucas, R.; Moot, D.; Morris, S.T.; et al. New Zealand's Pastoral Industries: Efficient Use of Pastoral Resources. In Grasslands: Developments, Opportunities, Perspectives; Reynolds, S.G., Frame, J., Eds.; CRS Press, Tylor \& Francis Group: Rome, Italy, 2005; Volume 46, p. 2304 , ISBN 9781578083596. [CrossRef]

8. Basher, L.; Moores, J.; McLean, G. Scientific Basis for Erosion and Sediment Control Practices in New Zealand; Landcare Research: Nelson, New Zealand, 2016.

9. Lambert, M.G.; Mackay, A.D.; Ganesh, S.; Upsdell, M.P. Responses of grazed New Zealand hill pastures to rates of superphosphate application. N. Z. J. Agric. Res. 2014, 57, 149-164. [CrossRef]

10. Praat, J.-P. Farming by Land Type: An Approach to Building Resilient Northland Sheep and Beef Farms; New Zealand Landcare Trust: Hamilton, New Zealand, 2011.

11. Norton, D.; Pannell, J. Desk-top assessment of Native Vegetation on New Zealand Sheep and Beef Farms; Beef + Lamb New Zealand: Wellington, New Zealand, 2018.

12. Eyles, G. Use of Poplars and Willows for Erosion Control. Available online: https://www.nzffa.org.nz/farm-forestry-model/ resource-centre/tree-grower-articles/november-2010/use-of-poplars-and-willows-for-erosion-control/ (accessed on 11 October 2020).

13. Basher, L. Erosion Processes and Their Control in New Zealand. In Ecosystem Services in New Zealand: Conditions and Trends; Dymond, J.R., Ed.; Manaaki Whenua Press: Lincoln, New Zealand, 2013; pp. 363-374, ISBN 978-0-478-34736-4.

14. McIvor, I.R.; Douglas, G.B. Poplars and Willows in Hill Country-Stabilising Soils and Storing Carbon; The New Zealand Institute for Plant \& Food Research Limited: Palmerston North, New Zealand, 2012.

15. Kemp, P.D.; Barry, T.N.; Douglas, G.B. Edible forage yield and nutritive value of poplar and willow. NZGA Res. Pract. Ser. 2003, 10, 53-64. [CrossRef]

16. Jones, T.; Mcivor, I. Willows and Poplars for Drought Mitigation. Available online: https:/ /www.nzfffa.org.nz/farm-forestrymodel/resource-centre/tree-grower-articles/november-2013/willows-and-poplars-for-drought-mitigation (accessed on 10 July 2020).

17. Ministry for Primary Industries. A guide to Carbon Look-up Tables for Forestry in the Emissions Trading Scheme; Ministry for Primary Industries: Wellington, New Zealand, 2017.

18. Charlton, D.; McIvor, I.; Gawith, P.; Douglas, G.; Deric, C.; McIvor, I.; Gawith, P.; Douglas, G. Growing Poplar and Willow Trees on Farms-Guidelines for Establishing and Managing Poplar and Willow Trees on Farms; National Poplar and Willow Users Group: Palmerston North, New Zealand, 2006.

19. Farming with Native Trees: A Guide for Farmers from Northland to Waikato; Dodd, M.; Ritchie, H. (Eds.) New Zealand Forest Research Institute Limited: Rotorua, New Zealand, 2007; ISBN 9780478110180.

20. Kimberley, M.; Bergin, D.; Beets, P. Carbon Sequestration by Planted Native Trees and Shrubs; Tāne' Tree Trust: Wellington, New Zealand, 2014.

21. Beets, P.N.; Kimberley, M.O.; Paul, T.S.H.; Oliver, G.R.; Pearce, S.H.; Buswell, J.M. The inventory of carbon stocks in New Zealand's post-1989 natural forest for reporting under the Kyoto Protocol. Forests 2014, 5, 2230-2252. [CrossRef]

22. Beef + Lamb NZ. Native Vegetation on Sheep and Beef Farms. Summary Report; Beef + Lamb New Zealand: Wellington, New Zealand, 2018.

23. Bryant, J.R.; Snow, V.O. Modelling pastoral farm agro-ecosystems: A review. N. Z. J. Agric. Res. 2008, 51, 349-363. [CrossRef]

24. Farrell, L.J. Bio-Economic System-Dynamics Modelling to Investigate Strategic Management Options in New Zealand Sheep Farming Enterprises. Ph.D. Thesis, Massey University, Palmerston North, New Zealand, 2020.

25. Farrell, L.J.; Tozer, P.R.; Kenyon, P.R.; Ramilan, T.; Cranston, L.M. The effect of ewe wastage in New Zealand sheep and beef farms on flock productivity and farm profitability. Agric. Syst. 2019, 174, 125-132. [CrossRef]

26. Farrell, L.J.; Kenyon, P.R.; Tozer, P.R.; Ramilan, T.; Cranston, L.M. Quantifying sheep enterprise profitability with varying flock replacement rates, lambing rates, and breeding strategies in New Zealand. Agric. Syst. 2020, 184, 102888. [CrossRef]

27. Farrell, L.J.; Kenyon, P.R.; Tozer, P.R.; Morris, S.T. Determining the impact of hogget breeding performance on profitability under a fixed feed supply scenario in New Zealand. Animals 2021, 11, 1303. [CrossRef]

28. Farrell, L.J.; Morris, S.T.; Kenyon, P.R.; Tozer, P.R. Simulating beef cattle herd productivity with varying cow liveweight and fixed feed supply. Agriculture 2021, 11, 35. [CrossRef] 
29. Hendy, J.; Ausseil, A.-G.; Bain, I.; Blanc, É.; Fleming, D.; Gibbs, J.; Hall, A.; Herzig, A.; Kavanagh, P.; Kerr, S.; et al. Land-Use Modelling in New Zealand: Current Practice and Future Needs. SSRN Electron. J. 2019. [CrossRef]

30. Bicknell, K.; Edwards, P.; Trafford, G.; Dooley, L. Farm System Modelling in New Zealand Literature Review; Dairy NZ: Hamilton, New Zealand, 2015.

31. Farrell, L.J.; Kenyon, P.R.; Morris, S.T.; Tozer, P.R. The impact of hogget and mature flock reproductive success on sheep farm productivity. Agriculture 2020, 10, 566. [CrossRef]

32. Farrell, L.J.; Morris, S.T.; Kenyon, P.R.; Tozer, P.R. Modelling a transition from purebred Romney to fully shedding WiltshireRomney crossbred. Animals 2020, 10, 2066. [CrossRef]

33. López, I.F.; Lambert, M.G.; Mackay, A.D.; Valentine, I. The influence of topography and pasture management on soil characteristics and herbage accumulation in hill pasture in the North Island of New Zealand. Plant Soil 2003, 255, 421-434. [CrossRef]

34. Bay of Plenty Regional Council. Uses and Management of Exotic Species: Poplars and Willows for Soil Conservation; Land Management Factsheet; Bay of Plenty Regional Council: Tauranga, New Zealand, 2020.

35. Moot, D.; Mills, A.; Lucas, D.; Scott, W. Country Pasture/Forage Resource Profiles: New Zealand; Food and Agriculture Organization of the United Nations (FAO): Rome, Italy, 2009.

36. Cranston, L.; Ridler, A.; Greer, A.; Kenyon, P.R. Livestock production in New Zealand. In Livestock Production in New Zealand; Stafford, K., Ed.; Massey University Press: Palmerston North, New Zealand, 2017; p. 304, ISBN 0994136315.

37. Beef+Lamb NZ. Economic Service Sheep \& Beef Farm Survey: Gisborne/Hawkes Bay/Wairarapa 2020-21 Forecast and Quintile Analysis of Final 2018-19 Survey Data I P20018; Beef + Lamb New Zealand: Wellington, New Zealand, 2020.

38. Lynn, I.; Manderson, A.; Page, M.; Harmsworth, G.; Eyles, G.; Douglas, G.; Mackay, A.; Newsome, P. Land Use Capability Survey Handbook, 3rd ed.; AgResearch Ltd.: Hamilton, New Zealand; Landcare Research New Zealand Ltd.: Lincoln, New Zealand; Institute of Geological and Nuclear Sciences Ltd., Lower Hutt: Wellington, New Zealand, 2009; ISBN 9780477100915.

39. Saggar, S.; Giltrap, D.L.; Davison, R.; Gibson, R.; de Klein, C.A.M.; Rollo, M.; Ettema, P.; Rys, G. Estimating direct $\mathrm{N}_{2} \mathrm{O}$ emissions from sheep, beef, and deer grazed pastures in New Zealand hill country: Accounting for the effect of land slope on the N2O emission factors from urine and dung. Agric. Ecosyst. Environ. 2015, 205, 70-78. [CrossRef]

40. Lambie, S.; Marden, M.; Kirschbaum, M.; Soliman, T.; Walsh, P.; Landcare, M.W. Best Options for Land Use Following Radiata Harvest in the Gisborne District under Climate Change: Literature Review; SLMACC 405415; Ministry for Primary Industries: Wellington, New Zealand, 2018; Volume 4.

41. Spiekermann, R.; Marden, M. Best Options for Land Use Following Radiata Harvest in the Gisborne District under Climate Change: Spatial Analysis of Erosion Susceptibility in Plantation Forests, East Coast Region; MPI Technical Paper; Ministry for Primary Industries: Wellington, New Zealand, 2018; Volume 1.

42. Hedley, C.; Manderson, A.; Mudge, P.; Roudier, P.; Fraser, S.; Parfitt, R.; Smaill, S.; Schipper, L.; Kelliher, F. Improved Measurements of Hill Country Soil Carbon-To Assist Carbon Change Studies; Ministry for Primary Industries: Wellington, New Zealand, 2015; Volume 2.

43. Burggraaf, V.; Stevens, D.; Vibart, R. The Effect of Grazing State on Pasture Quality and Implications for the New Zealand Greenhouse Gas Inventory; Final Report; Ministry for Primary Industries: Wellington, New Zealand, 2018; Volume 9.

44. Marden, M.; Fuller, I.C.; Herzig, A.; Betts, H.D. Badass gullies: Fluvio-mass-movement gully complexes in New Zealand's East Coast region, and potential for remediation. Geomorphology 2018, 307, 12-23. [CrossRef]

45. Lambert, M.G.; Clark, D.A.; Grant, D.A.; Costall, D.A.; Fletcher, R.H. Influence of fertiliser and grazing management on north island moist hill country: 1. Herbage accumulation. N. Z. J. Agric. Res. 1983, 26, 95-108. [CrossRef]

46. Ledgard, S.F.; Sheath, G.W.; Gillingham, A.G. Influence of some soil and pasture components on the growth of hill country pastures 1. Winter and spring production. N. Z. J. Exp. Agric. 1982, 10, 239-244. [CrossRef]

47. Harmsworth, G.R. Land Use Capability Classification of the Northland Region: A Report to Accompany the Second Edition New Zealand Land Resource Inventory; Manaaki Whenua Press: Canterbury, New Zealand, 1996.

48. Page, M.J. Land Use Capability Classification of the Northern Hawke's Bay Region; Ministry of Works and Development: Wellington, New Zealand, 1988.

49. Murray, R.J.; Crippen, T.F.; Page, M.J.; Rijkse, W.C.; Harmsworth, G.R.; Mcleod, M. Land Use Capability Classification of the Gisborn-East Coast Region; Manaaki Whenua Press: Canterbury, New Zealand, 1999.

50. Cameron, D. Sustaining the productivity of New Zealand's hill country-A land manager's view. NZGA Res. Pract. Ser. 2016, 16, 151-155. [CrossRef]

51. Farrell, L.J.; Tozer, P.R.; Kenyon, P.R.; Ramilan, T.; Cranston, L.M. Producing higher value wool through a transition from Romney to Merino crossbred i: Flock dynamics, feed demand, and production of lambs and wool. Small Rumin. Res. 2020, 192, 106212. [CrossRef]

52. Webby, R.W.; Bywater, A.C. Principles of feed planning and management. In Pasture and Supplements for Grazing Animals; Rattray, P., Brookes, I.M., Nicol, A.M., Eds.; New Zealand Society of Animal Production (Inc.): Hamilton, New Zealand, 2017; p. 339, ISBN 0473052369.

53. Nicol, A.M.; Brookes, I.M. The metabolisable energy requirements of grazing livestock. In Pasture and Supplements for Grazing Animals; Rattray, P.V., Brookes, I.M., Nicol, A.M., Eds.; New Zealand Society of Animal Production (Inc.): Hamilton, New Zealand, 2017; p. 339, ISBN 0473052369. 
54. Beef+Lamb NZ. A Guide to Feed Planning for Sheep Farmers; Beef+Lamb NZ: Wellington, New Zealand, 2012.

55. Trafford, G.; Trafford, S. (Eds.) Farm Technical Manual; Faculty of Commerce, Lincoln University: Christchurch, New Zealand, 2011; ISBN 9780864762573.

56. Paine, C.E.T.; Marthews, T.R.; Vogt, D.R.; Purves, D.; Rees, M.; Hector, A.; Turnbull, L.A. How to fit nonlinear plant growth models and calculate growth rates: An update for ecologists. Methods Ecol. Evol. 2012, 3, 245-256. [CrossRef]

57. Cao, L.; Shi, P.J.; Li, L.; Chen, G. A new flexible sigmoidal growth model. Symmetry 2019, 11, 204. [CrossRef]

58. McKenzie, H.; Hay, E. Performance of Eucalyptus saligna in New Zealand; New Zealand Forest Research Institute: Rotorua, New Zealand, 1996.

59. Oppong, S.K.; Kemp, P.D.; Douglas, G.B.; Foote, A.G. Browse yield and nutritive value of two Salix species and Dorycnium rectum in New Zealand. Agrofor. Syst. 2001, 51, 11-21. [CrossRef]

60. Ma, S.; He, F.; Tian, D.; Zou, D.; Yan, Z.; Yang, Y.; Zhou, T.; Huang, K.; Shen, H.; Fang, J. Variations and determinants of carbon content in plants: A global synthesis. Biogeosciences 2018, 15, 693-702. [CrossRef]

61. Marden, M.; Lambie, S.; Phillips, C. Biomass and root attributes of eight of New Zealand's most common indigenous evergreen conifer and broadleaved forest species during the first 5 years of establishment. N. Z. J. For. Sci. 2018, 48, 1-26. [CrossRef]

62. Poorter, H.; Niklas, K.J.; Reich, P.B.; Oleksyn, J.; Poot, P.; Mommer, L. Biomass allocation to leaves, stems and roots: Meta-analyses of interspecific variation and environmental control. New Phytol. 2012, 193, 30-50. [CrossRef]

63. Marden, M.; Rowan, D.; Phillips, C. Stabilising characteristics of New Zealand indigenous riparian colonising plants. Plant Soil 2005, 278, 95-105. [CrossRef]

64. Mason, N.W.H.; Beets, P.N.; Payton, I.; Burrows, L.; Holdaway, R.J.; Carswell, F.E. Individual-based allometric equations accurately measure carbon storage and sequestration in shrublands. Forests 2014, 5, 309-324. [CrossRef]

65. Benavides, R.; Douglas, G.B.; Osoro, K. Silvopastoralism in New Zealand: Review of effects of evergreen and deciduous trees on pasture dynamics. Agrofor. Syst. 2009, 76, 327-350. [CrossRef]

66. Devkota, N.R.; Kemp, P.D.; Hodgson, J.; Valentine, I.; Jaya, I.K.D. Relationship between tree canopy height and the production of pasture species in a silvopastoral system based on alder trees. Agrofor. Syst. 2009, 76, 363-374. [CrossRef]

67. McElwee, H.F.; Knowles, R.L. Estimating canopy closure and understorey pasture production in New Zealand-grown poplar plantations. N. Z. J. For. Sci. 2000, 30, 422-435.

68. Hussain, Z.; Kemp, P.D.; Horne, D.J.; Jaya, I.K.D. Pasture production under densely planted young willow and poplar in a silvopastoral system. Agrofor. Syst. 2009, 76, 351-362. [CrossRef]

69. Scanlan, I.; McElhinny, C.; Turner, P. A Methodology for modelling canopy structure: An exploratory analysis in the tall wet eucalypt forests of southern Tasmania. Forests 2010, 1, 4-24. [CrossRef]

70. Sanon, H.O.; Kaboré-Zoungrana, C.; Ledin, I. Behaviour of goats, sheep and cattle and their selection of browse species on natural pasture in a Sahelian area. Small Rumin. Res. 2007, 67, 64-74. [CrossRef]

71. McEvoy, P.M.; McAdam, J.H. Sheep grazing in young oak Quercus spp. and ash Fraxinus excelsior plantations: Vegetation control, seasonality and tree damage. Agrofor. Syst. 2008, 74, 199-211. [CrossRef]

72. Mäkelä, A. A Carbon Balance Model of Growth and Self-Pruning in Trees Based on Structural Relationships. For. Sci. 1997, 43, 7-24.

73. Farrell, L.J.; Tozer, P.R.; Kenyon, P.R.; Ramilan, T.; Cranston, L.M. Producing higher value wool through a transition from Romney to Merino crossbred ii: Cashflow and profit. Small Rumin. Res. 2020, 192, 106236. [CrossRef]

74. Mathilde, B. Long Term Carbon Price Data; Carbon Forest Services: Wellington, New Zealand, 2021.

75. Beef+Lamb NZ. A Guide to Feed Planning for Sheep Farmers; Beef+Lamb NZ: Wellington, New Zealand, 2018.

76. Kemp, P.D.; Mackay, A.D.; Matheson, L.A.; Timmins, M.E. The forage value of poplars and willows. Proc. N. Z. Grassl. Assoc. 2001, 63, 115-119. [CrossRef]

77. Brookshire, E.N.J.; Kauffman, J.B.; Lytjen, D.; Otting, N. Cumulative effects of wild ungulate and livestock herbivory on riparian willows. Oecologia 2002, 132, 559-566. [CrossRef]

78. Ouédraogo-Koné, S.; Kaboré-Zoungrana, C.Y.; Ledin, I. Behaviour of goats, sheep and cattle on natural pasture in the sub-humid zone of West Africa. Livest. Sci. 2006, 105, 244-252. [CrossRef]

79. Hopkinson, M. Net Present Value and Risk Modelling for Projects; Routledge, Taylor \& Francis Group: New York, NY, USA, 2016; ISBN 9781351915267. [CrossRef]

80. Beef+Lamb NZ. Annual Report 2016-17; Beef+Lamb NZ: Wellington, New Zealand, 2017.

81. Evison, D. A method for comparing investment returns from major rural land uses including forestry. N. Z. J. For. 2008, 53, 27-32.

82. Herbohn, J.; Harrison, S. Socio-economic research methods in forestry: A training manual. In Proceedings of the International Training Workshop, Baybay, Philippines, 4-10 February 2002; Harrison, S., Herbohn, J., Mangaoang, E., Vanclay, J., Eds.; Cooperative Research Centre for Tropical Rainforest Ecology and Management: Queensland, Australia, 2002 ; p. 238.

83. The Treasury. Public Sector Discount Rates for Cost Benefit Analysis; The Treasury: Wellington, New Zealand, 2008.

84. Reserve Bank of New Zealand Retail Interest Rates on Lending and Deposits (B3). Available online: https://www.rbnz.govt.nz/ statistics/b3 (accessed on 13 August 2021). 
85. Bergin, D. (Ed.) Planting and Managing Native Trees. In Tāne' Tree Trust Technical Handbook; Tāne' Tree Trust: Wellington, New Zealand, 2014; p. 243.

86. Pollock, K.M. Plant Materials Handbook for Soil Conservation: Native Plants; Water and Soil Direclorate, Ministry of Works and Development: Wellington, New Zealand, 1986; Volume 3.

87. Saunders, L. The Mānuka and Kānuka Plantation Guide; Boffa Miskell Limited: Wellington, New Zealand, 2017.

88. Fernandez, M.A. Adoption of erosion management practices in New Zealand. Land Use Policy 2017, 63, 236-245. [CrossRef]

89. Carver, T.; Kerr, S. Facilitating Carbon Offsets from Native Forests; Motu Economic and Public Policy Research: Wellington, New Zealand, 2017.

90. Ministry for the Environment \& Stats NZ. New Zealand's Environmental Reporting Series: Environment Aotearoa 2019; Ministry for the Environment \& Stats NZ: Wellington, New Zealand, 2019.

91. Rae, A.; Nixon, C.; Lattimore, R. Adjustment to Agricultural Policy Reform-Issues and Lessons from the New Zealand Experience; NZ Trade Consortium Working Paper; New Zealand Institute of Economic Research (NZIER): Wellington, New Zealand, 2004.

92. Smith, W.; Montgomery, H. Revolution or evolution? New Zealand agriculture since 1984. GeoJournal 2004, 59, 107-118. [CrossRef]

93. Morris, S.T. Economics of sheep production. Small Rumin. Res. 2009, 86, 59-62. [CrossRef]

94. Crean, M.J. Revealing the true meaning of the IRR via profiling the IRR and defining the ERR. J. Real Estate Portf. Manag. 2005, 11, 323-330. [CrossRef]

95. Patrick, M.; French, N. The internal rate of return (IRR): Projections, benchmarks and pitfalls. J. Prop. Invest. Financ. 2016, 34, 664-669. [CrossRef]

96. Manley, B. Impacts of Carbon Prices on Indicators of Competitiveness; MPI Technical Paper No: 2019/13; Ministry for Primary Industries: Wellington, New Zealand, 2019.

97. Carver, T.; Dawson, P.; Kerr, S. Including Forestry in an Emissions Trading Scheme: Lessons from New Zealand. SSRN Electron. J. 2018. [CrossRef] 